\title{
Tiller population density and productivity in tall fescue and prairie grass swards
}

\author{
Jorge Scheneiter ${ }^{1}$, and Silvia Assuero ${ }^{2}$ \\ 'Instituto Nacional de Tecnología Agropecuaria, EEA Pergamino. Avda. Frondizi, km 4,5, B2700WAA, \\ Pergamino, Provincia de Buenos Aires, República Argentina. \\ ${ }^{2}$ Facultad Ciencias Agrarias. Universidad Nacional de Mar del Plata. Ruta Nacional 226, CC 276 (7620), \\ Balcarce, Provincia Buenos Aires, Argentina.
}

\begin{abstract}
J. Scheneiter, and S. Assuero. 2010. Tiller population density and productivity in tall fescue and prairie grass swards. Cien. Inv. Agr. 37(2): 35-44. This study examined the relationship between herbage mass and tiller population density in terms of size/density compensation theory, in tall fescue (Festuca arundinacea Schreb.) and prairie grass (Bromus catharticus Vhal) swards. Tall fescue herbage mass and tiller density information was collected from an experiment where two nitrogen levels, two seeding arrangements and two grazing frequencies were evaluated. In prairie grass, the same information was obtained from swards managed with two levels of defoliation frequency and intensity. In tall fescue size density compensation mechanisms were observed when nitrogen nutrition limitation was overcome. Prairie grass showed less phenotypic plasticity than tall fescue and density/compensation mechanisms were less evident.
\end{abstract}

Key words: Festuca arundinacea, Bromus catharticus, herbage mass, tillers, size/density compensation.

\section{Introduction}

Density of tillers in a grass sward is a current agronomic indicator of productivity and persistence. However, the quantitative relationship between density and productivity is more difficult to establish and there was little research in South America swards. In the North of Buenos Aires Province, for example, Bertín (1988) determined in tall fescue, a density of $\leq 1,000$

Received April 22, 2009. Accepted July 27, 2009.

Corresponding author: oscheneiter@pergamino.inta.gov.ar tillers $\mathrm{m}^{-2}$ under cutting and 2,300 tillers $\mathrm{m}^{-2}$ under semi-continuous grazing for the period August-September. However, this sward is not expected to produce more than double herbage mass under grazing than under cutting, with similar environmental conditions and defoliation intensities.

From the aforesaid statement, follows that tiller density per se may be not a reliable measure on sward productivity. This is due to the tiller size/ density compensation (SDC), which implies that a decrease in tiller density is accompanied by an increase in tiller size or vice versa, an increase of tiller population density, for smaller til- 
lers (Chapman and Lemaire, 1993). Therefore, variations in tiller density usually reflect SDC changes without a concomitant change in the accumulation of forage.

The variation in tiller density is an important mechanism to regulate the leaf area of a sward. In fact, the leaf area index (LAI) is determined by the tiller density, the number of leaves per tiller (value relatively constant for each species) and the leaf area (subordinate to defoliation intensity). Thus, conceptually, the SDC is a mechanism that optimizes the LAI of the sward (Matthew et al., 2000). In absence of disturbances by defoliation, with constant LAI and foliar area/ volume ratio of the tiller, it was determined that the SDC, at tiller level, is conveniently explained by a logarithmic size/density ratio with a -3/2 slope (Sackville Hamilton et al., 1995). At sward level, the SDC was found to be well defined by a $\log _{10}$ herbage mass ( $\mathrm{kg} \mathrm{DM} \mathrm{ha-1)/}$ $\log _{10}$ density ratio (tillers $\mathrm{m}^{-2}$ ), with a $-1 / 2$ slope (Matthew et al., 1995). This slope predicts the expected changes in the forage herbage mass by changes in the tiller density.

However, swards grow under variable conditions, as they are subject to changes in the environmental conditions and defoliation management. In the case of swards subjected to different defoliation managements, those that are defoliated with a less intensive and frequent defoliation regime will show a higher average LAI. Likewise, the change in the sward density may affect the leaf area/volume ratio of the tiller ("leafiness") due to the relative importance of the supporting tissues as the herbage mass increases. In order to deal with these issues, correction factors of theoretical SDC were proposed. For example, in perennial ryegrass, a factor of 2.05 for changes in the LAI $\left(\mathrm{C}_{\mathrm{a}}\right)$ and -0.16 for changes in the relation between leaf area and tiller volume $\left(\mathrm{C}_{\mathrm{r}}\right)$ were calculated (Matthew et al., 1995).

The SDC line corresponds to the equilibrium situation. In practice, after cutting or grazing, the swards undergo a series of phases until they reach the equilibrium. This concept was described by Matthew et al. (2000) (Figure 1).
Conceptually, the SDC line represents the maximum LAI ("environmental ceiling") reached by a sward, independently of tiller density and the supporting structures to maintain that LAI. These structures depend on sward density and the species. For example, a decreased number and an increased size of the individual tiller, increase the relative importance of the supporting tissues.

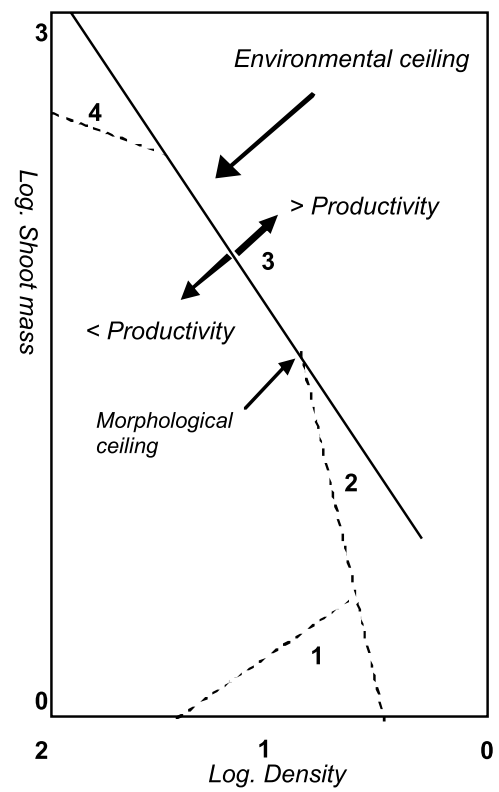

Figure 1. Shoot mass/tiller density relationships in four phases during sward regrowth under rotational grazing. 1. Indefinite relationship (fast increase of tiller density and weight). 2. Variable leaf area with SDC slope near - 2.5 (tiller population density stops and sward herbage mass continues increasing till maximum tiller size is attained -"Morphological ceiling"-). 3. Constant leaf area with SDC slope -1.5 ("Environmental ceiling"). 4. Constant herbage mass with SDC slope near -1.0. Adapted from Matthew et al. (1995).

Any change in tillers density or size without a corresponding change on the SDC line implies a displacement to a new LAI value of the sward. If the new value falls over the SDC line, this indicates that a higher LAI was reached, a variable generally associated to a higher productivity. The contrary occurs if the value falls under the SDC line (Figure 1). Based on that, an index of productivity was proposed, which consists of comparing the coordinates of size/density of tillers of a sward with the expected or theoretical SDC line (Matthew et al., 1996). 
Prairie grass (Bromus catharticus Vhal) and tall fescue (Festuca arundinacea Schreb.) are among the most used poaceae in the Pampean region, they are species with different characteristics in regard to their perennity and adaptation to defoliation intensity and frequency. The first species presents models of annual persistence or shortly perennial according to the defoliation management. It behaves like an annual species and its persistence depends on natural reseeding with infrequent and severe defoliation, while it behaves as a short perennial with frequent and lax defoliation management (Scheneiter et al., 2008). On the other hand, tall fescue is a perennial species, whose mechanism of persistence is based on a positive net balance of tillers from early fall to mid-spring, and a negative net balance from mid-spring to late summer (Scheneiter and Améndola, unpublished data).

The objective of this work was to compare the relationship between tiller density and productivity of tall fescue and prairie grass swards with the expectations according to the theory of size/density compensation of tillers. In order to do this, data obtained in two experiments were analyzed, one with tall fescue subjected to intermittent grazing and the other with prairie grass under different cutting managements.

\section{Materials and methods}

\section{Tall fescue experiment}

The information analyzed corresponds to an experiment performed between 2004 and 2008 to study tiller dynamics in swards of tall fescue with different sowing arrangements, fertilization levels and grazing frequencies. The experiment was carried out at Pergamino Experimental Station, INTA (33 $56^{\circ}$ 'S, $60^{\circ} 33^{\prime} \mathrm{W}, 66 \mathrm{~m}$ a.s.1.) The treatments were a combination of two fertilization levels $(0(\mathrm{~N}-)$ and $\left.200(\mathrm{~N}+) \mathrm{kg} \mathrm{N} \mathrm{ha}^{-1}\right)$, two sowing arrangements (Alternate and Crossed) and two grazing frequencies at $28(\mathrm{~F}+)$ and $56(\mathrm{~F}-)$ days of regrowth.
Nitrogen fertilization was performed in two applications of $100 \mathrm{~kg} \mathrm{~N} \mathrm{ha}^{-1}$ each, one at the end of summer and the other at the end of winter, using UAN (30-0-0) as source of N. The alternate sowing consisted on sowing alternate rows of tall fescue and white clover, $16 \mathrm{~cm}$ apart. The crossed sowing was performed in two times, first, tall fescue was sown in lines $16 \mathrm{~cm}$ apart and then the clover was sown in lines $17.5 \mathrm{~cm}$ apart, $90^{\circ}$ in regard to tall fescue rows. The grazing rotation frequencies were of 28 or 56 days of regrowth in order to provide contrasting herbage mass accumulations along the experimental period. The size of each experimental unit (EU) was 0.14 ha. British steers of the general herd of INTA Pergamino Experimental Station were used. Each EU was independently grazed for a period no longer than 3 days, adjusting the stocking rate to leave remaining stubble of $8-10 \mathrm{~cm}$.

Herbage mass, expressed on dry matter basis was determined before each grazing $(\mathrm{kg}$ DM ha $\left.{ }^{-1}\right)$. To do this, five samples per EU of $0.25 \mathrm{~m}^{2}$ each were cut at 5-7 cm height. Fresh samples were weighed and then an aliquot of $0.25 \mathrm{~kg}$ was taken and dried in an oven until constant weight was reached, to determine dry matter percentage. Tiller density was determined between December 2004 and January 2008 in three fixed $0.048 \mathrm{~m}^{-2}$ rectangular frames, installed in each EU. In December 2004, all the tillers present were identified. Subsequently, with a monthly frequency, all the new tillers appeared during the previous month were marked with rings of different color, and the number of dead tillers from the previous cohorts was recorded and their rings removed. With the data obtained, tiller density from each age cohort was determined and, for a specific month, tiller population density was estimated as the sum of the tillers of cohorts present in that month.

\section{Prairie grass experiment}

The information corresponds to an experiment performed between 1999 and 2001 to study the tiller dynamics of prairie grass subjected 
to different defoliation managements. The experiment was carried out at Pergamino Experimental Station, INTA. The treatments were the combination of two defoliation frequencies and two defoliation intensities. The frequencies were five cuts per year (F-), two in spring and one at the end of the rest of the seasons, and nine cuts a year $(\mathrm{F}+)$, three in spring and two the rest of the seasons. The defoliation intensities were 50 and $100 \mathrm{~mm}$ height from the soil level (I+ and I-, respectively). The swards were fertilized with $250 \mathrm{~kg} \mathrm{ha}^{-1}$ year ${ }^{-1}$ of calcareous ammonium nitrate $(27-28 \% \mathrm{~N})$ in three split dressings (midspring, end of spring and fall). Each EU had an area of $4.8 \mathrm{~m}^{2}$.

At each defoliation event, herbage mass of green forage was measured and expressed on dry matter basis (kg DM ha-1). Plots were cut with a motorscythe and the forage was collected and weighed immediately in the field. A $0.25 \mathrm{~kg}$ aliquot was extracted from the material harvested for dry matter determination, following the same procedure described above. Determinations of tiller density, as well as the net balance between rates of tiller appearance and death (Scheneiter et al., 2008) were monthly performed between March 2000 and April 2001, as described above.

\section{Experimental design and statistical analysis}

Tall fescue experiment. A split-split plot design was used with the sowing arrangement as main plot, $\mathrm{N}$ level as subplot and grazing frequency as sub-subplot $(\mathrm{n}=3)$.

Prairie grass experiment. A complete randomized block design was used with a factorial arrangement of two levels of defoliation frequency and two levels of defoliation intensity $(n=4)$.

To compare the information from these two experiments with the results expected according to the SDC theory, data obtained from vegetative and reproductive regrowths, under non limiting environmental conditions were used. Under favourable growing conditions, encouraged competence among tillers at the end of each regrowth period was expected. Therefore, from the entire information available in both experiments, five regrowths in tall fescue and three in prairie grass were selected, which corresponded to dense swards and periods where environmental conditions did not present important deviations in regard to the historical averages (monthly rainfall $\pm 40 \%$ and monthly mean air temperatures $\pm 15 \%$ ).

Data from herbage mass and tiller population density were log transformed and then linear regressions were fitted by the Standardised Major Axis Method (SMA), using the program SMATR v. 2.0 (Warton et al., 2006). In tall fescue, the values of both sowing arrangements were averaged because interactions of this treatment with the grazing frequency or the nitrogen level were not significant.

\section{Results and discussion}

\section{Tall fescue experiment}

In this experiment, tall fescue was the main component of the sward and contributed, in average, with more than $95 \%$ of the herbage mass. Other species were white clover and weeds. The proportion of the legume decreased from sward establishment onwards, until it disappeared in the last year of the experiment. The presence of spontaneous species was prevented by the application of herbicides when it was necessary.

The relation between herbage mass and tiller density is shown in Figure 2. With the N- treatment, a phase with a simultaneous increase in herbage mass and in tiller density, was observed when the regrowth was extended from 28 to 56 days. In this case, and in contrast with $\mathrm{N}+$ treatment, the nutritional restriction limited the development of a closed canopy (0.72 and $1.09 \mathrm{t} \mathrm{DM} \mathrm{ha}^{-1}$ for F+N- and F-N-, respectively, $\mathrm{p}<0.01$ ). According to Figures 1 and 2, the "environmental ceiling" was not even reached at 56 days of regrowth. 


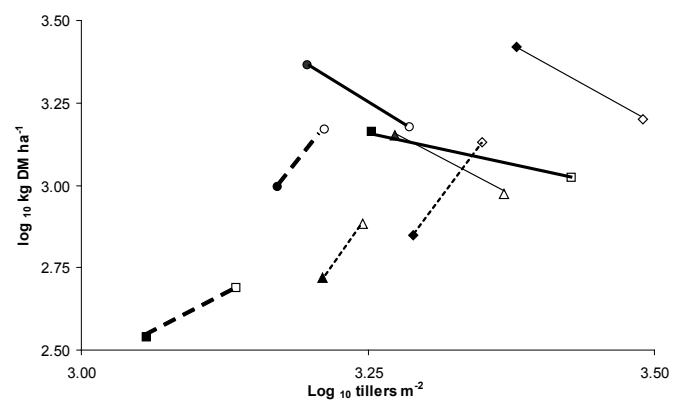

Figure 2. Effect of nitrogen level and grazing frequency on tiller size density compensation in different regrowths of tall fescue swards during the experimental period. References: full line $\mathrm{N}+$, dotted line $\mathrm{N}$-, empty symbol F+, full symbol F-, diamond Sept. 2005, square Oct. 2006, circle May 2006, triangle Jul. 2005.

With less constraining conditions and an annual fertilization of $200 \mathrm{~kg} \mathrm{~N} \mathrm{ha}^{-1}$, the herbage mass /density coordinates with 28 and 56 days of regrowth were located in a trajectory indicating SDC relations, optimizing the productivity of the treatments. Consequently, we will only refer to this last situation.

The linear model obtained between herbage mass and tiller density was significant in most of the periods studied, although the values of the coefficients of determination were intermediate or low (Table 1). The empirical slopes were significant, and more negative than the theoretical value $-1 / 2$ in all the cases. However, when the theoretical slope was corrected by the increased LAI, the regrowth period was extended from 28 to 56 days $\left(-\left(\mathrm{C}_{\mathrm{a}}+1 / 2\right)\right.$; Table 2$)$, the values estimated were even more negative than the empirical values. According to these slopes, the reduction of tillers density as herbage mass increased was higher than expected. In this analysis, the correction that takes into account the relation between tiller leaf surface area and tiller volume $(\mathrm{Cr})$ was omitted as that would have made slope less negative (Sackville Hamilton et al., 1995), and therefore, reduce the difference between the empirical and theoretical values. In perennial ryegrass and Rhodes grass, the changes obtained by other authors in the value of the SDC slope with the introduction of $\mathrm{C}_{\mathrm{r}}$ in the equation, were in the range of 5-8\% (Matthew et al., 1995; Martínez Calsina, 2008).

Table 1. $\log _{10}$ herbage mass $/ \log _{10}$ tiller density regressions in tall fescue swards with 28 and 56 days of regrowth, in different experimental periods.

\begin{tabular}{lcccc}
\hline Period & Intercept & Slope & $\mathrm{P}<\mathrm{F}$ & $\mathrm{R}^{2}$ \\
\hline Aug.-Sept. '05 & 8.48 & -1.52 & 0.012 & 0.48 \\
Nov.-Dec. '05 & 7.69 & -1.49 & 0.001 & 0.70 \\
Mar.-Jun. '06 & 8.76 & -1.68 & 0.017 & 0.23 \\
Nov.-Dec. '06 & 5.79 & -0.78 & 0.070 & 0.32 \\
Jan.-Feb. '07 & 13.76 & -3.38 & 0.017 & 0.45 \\
\hline
\end{tabular}

In F- treatment, a lower tiller density and higher herbage mass were observed when compared with F+, in March-June 2006 (Figure 3a) and in November-December 2005 (Figure 3b). The values corresponding to frequent grazing tended to fall under the line of empirical compensation. Figures 2 and 3 indicate the possible maximum values of the tiller density, since higher values

Table 2. Tiller density, Leaf Area Index and $\mathrm{C}_{\mathrm{a}}$ value in tall fescue swards with 28 and 56 days of regrowth, in different experimental periods.

\begin{tabular}{|c|c|c|c|c|c|c|c|c|c|c|}
\hline \multirow[b]{4}{*}{ Variable } & \multicolumn{10}{|c|}{ Period } \\
\hline & \multirow{2}{*}{\multicolumn{2}{|c|}{$\begin{array}{c}\text { Aug.-Sept. } \\
2005\end{array}$}} & \multirow{2}{*}{\multicolumn{2}{|c|}{$\begin{array}{l}\text { Nov.-Dec. } \\
2005\end{array}$}} & \multirow{2}{*}{\multicolumn{2}{|c|}{$\begin{array}{c}\text { Mar.-Jun. } \\
2006\end{array}$}} & \multirow{2}{*}{\multicolumn{2}{|c|}{$\begin{array}{c}\text { Nov.-Dec. } \\
2006\end{array}$}} & \multirow{2}{*}{\multicolumn{2}{|c|}{$\begin{array}{c}\text { Jan.-Feb. } \\
2007\end{array}$}} \\
\hline & & & & & & & & & & \\
\hline & $\mathrm{F}^{+}$ & $\mathrm{F}^{-}$ & $\mathrm{F}^{+}$ & $\mathrm{F}^{-}$ & $\mathrm{F}^{+}$ & $\mathrm{F}^{-}$ & $\mathrm{F}^{+}$ & $\mathrm{F}^{-}$ & $\mathrm{F}^{+}$ & $\mathrm{F}^{-}$ \\
\hline $\begin{array}{l}\text { Density } \\
{\text { (tillers } \mathrm{m}^{2} \text { ) }}\end{array}$ & 2,836 & 2,179 & 1,746 & 1,278 & 2,552 & 1,814 & 1,805 & 1,303 & 1,518 & 1,249 \\
\hline $\mathrm{LAI}^{1}$ & 5.9 & 7.4 & 1.6 & 2.0 & 3.8 & 5.9 & 3.8 & 4.4 & 3.0 & 5.0 \\
\hline $\mathrm{C}_{\mathrm{a}}^{2}$ & \multicolumn{2}{|c|}{1.32} & \multicolumn{2}{|c|}{1.26} & \multicolumn{2}{|c|}{1.95} & \multicolumn{2}{|c|}{0.69} & \multicolumn{2}{|c|}{3.89} \\
\hline
\end{tabular}

${ }^{1}$ Estimated from Scheneiter (2006) and unpublished data.

${ }^{2} \mathrm{C}_{\mathrm{a}}=\left(\log _{10}\left(\mathrm{LAI}_{56}\right)^{3 / 2}-\log _{10}\left(\operatorname{LAI}_{28}\right)^{3 / 2}\right) /\left(\log _{10}\left(\right.\right.$ tillers.m $\left.{ }^{-2}{ }_{56}\right)-\log _{10}\left(\right.$ tillers.m $\left.\left.{ }^{-2}{ }_{28}\right)\right)$. 
are unlikely to be found, and they would be the plastic limit of the species for the North of Buenos Aires Province.

The herbage mass accumulated in each grazing was twice as much in $\mathrm{F}$ - in comparison to $\mathrm{F}+$ (average for three years, 2,064 and 1,013 kg $\mathrm{DM} \mathrm{ha}^{-1}$, respectively). However, it must also be taken into account that there was twice as much grazing event in $\mathrm{F}+$ compared to $\mathrm{F}$ - (13 and 6.5 grazings per year, respectively). Thus, the herbage mass offered to the animals along the year was similar. Therefore, in dense tall fescue swards, under non-limiting growth conditions, it is possible to increase the herbage mass accumulation of the sward, if the regrowth period is extended, through compensatory changes in tiller density and tiller size. However, this kind of management might have negative consequences on the nutritional quality of forage (Marino and Agnusdei, 2004) and on the production of the following regrowth if the subsequent resting period in not long enough (Parsons, 1988). On the other hand, it is possible to promote tillering by increasing the grazing frequency to obtain a similar productivity and high quality forage. Although this mechanism seems to find a ceiling tiller density that varies depending on the time of the year (1,950 tillers $\mathrm{m}^{-2}$ in May and 3,100 tillers $\mathrm{m}^{-2}$ in October). Occasionally, densities of around 4,000 tillers $\mathrm{m}^{-2}$ were recorded in the site of the experiment associated to a forage herbage mass of around 700 to $1,000 \mathrm{~kg} \mathrm{DM} \mathrm{ha}^{-1}$.

The same general behaviour was observed by Rolhauser et al. (2007) in tall fescue, at a level of higher aggregation of the individuals ("tussock"), when one versus four cuts per year were compared at two levels of nitrogen fertilization ( 0 and $50 \mathrm{~kg} \mathrm{~N} \mathrm{ha}^{-1}$ year ${ }^{-1}$ ). These authors found that the basal diameter of the tussocks was increased by $\mathrm{N}$ fertilization but was not modified by the defoliation treatments. However, with $\mathrm{N}$ treatments, more tussocks with lower basal diameter were observed in the swards that received four cuts per year when compared to

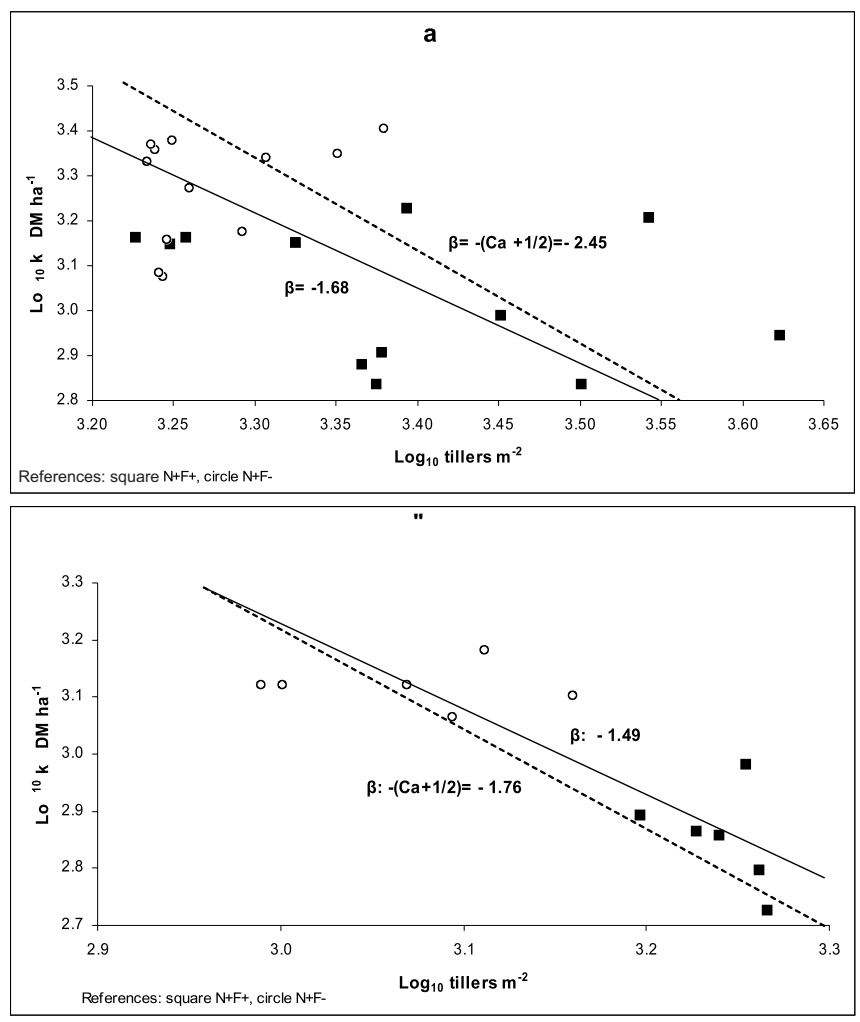

Figure 3. Effect of defoliation frequency on herbage mass/density relationship in tall fescue swards fertilized with nitrogen a: Mar.-Jun. de 2006, b: Nov.-Dec. 2005. References: full line: empiric slope, dotted line: theoretical slope, square: F+, circle: F-. 
those that received only one cut per year.

In summer, the maintenance of low and dense swards is not recommended in the North of Buenos Aires Province, since when the season is excessively hot and dry, the tiller population density of the sward decreases, the establishment of invading species is favored and forage accumulation is reduced (Scheneiter et al., 2001).

\section{Prairie grass experiment}

Prairie grass has been identified as one species where the compensatory changes are less evident than in perennial ryegrass (Xia et al., 1994). Likewise, in comparison with other species, it has shown a lower tillering capacity, although the tillers it produces are larger (Campo et al., 1998). It was also observed that after two years of establishment, swards of prairie grass subjected to intense defoliation showed a lower tiller density than those subjected to a less intensive management (Scheneiter et al., 2008).

As the experiment progressed, the data presented for prairie grass showed a different behaviour as compared with tall fescue (Table 3). For instance, the slopes of the SDC lines estimated from May to September were progressively more negative and statistically different between each other $(p<0.001$; test for common slopes). Afterwards, the relationship was reversed, indicating that the sward growth was limited by some environmental factor.

Table 3. $\log _{10}$ herbage mass $/ \log _{10}$ tiller density regressions in prairie grass swards with different defoliation managements.

\begin{tabular}{lcccc}
\hline Period & Intercept & Slope & $\mathrm{P}<\mathrm{F}$ & $\mathrm{R}^{2}$ \\
\hline May 2000 & 5.58 & -0.75 & 0.021 & 0.33 \\
September 2000 & 9.22 & -1.79 & 0.004 & 0.46 \\
December 2000 & -1.11 & 1.35 & 0.006 & 0.43 \\
\hline
\end{tabular}

Figures $4 a-c$ show how the effect of the frequency and intensity of the defoliation on the SDC relationships evolved in time. Therefore in May, with a slope close to $-1 / 2$ (Figure $4 a$ ), the coordinates of the treatments show that tiller density increased under the infrequent and less intense defoliation management. This is a characteristic of the species that makes it less tolerant than perennial ryegrass and tall fescue to severe grazing managements. The value of the slope found $(-0.75)$ is less negative than the theoretical value $(-1.13)(-(\mathrm{Ca}+1 / 2))$, although as in the case of tall fescue, the inclusion of the $\mathrm{C}_{\mathrm{r}}$ value in the correction of the theoretical gradient would have reduced the differences between the value found and the theoretical value.
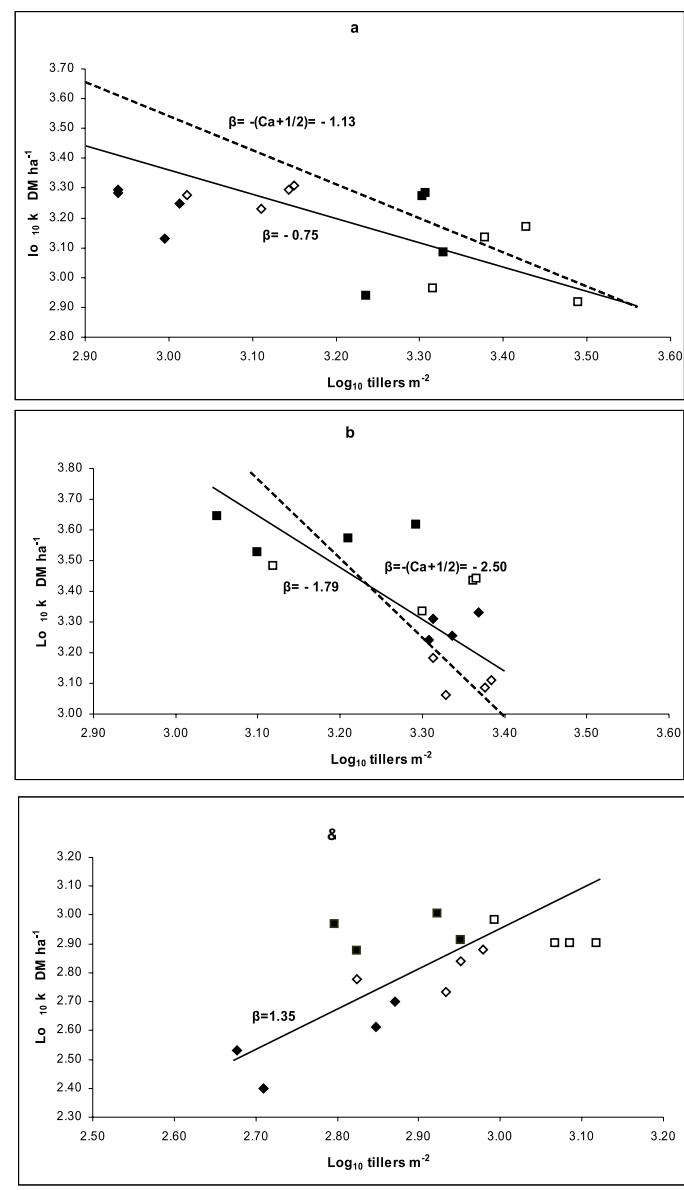

Figure 4. Effect of defoliation frequency and severity on herbage mass/density relationship in prairie grass swards a: May.; b: Sept.; c: Dec. 2000. References: full line: empiric slope, dotted line: theoretical slope, full diamond $\mathrm{F}+\mathrm{I}+$, empty diamond F+ I-, full square F- I+, empty square F- I-

In September, at the beginning of the reproductive state, it was observed that the treatments with frequent defoliation had a higher tiller density but lower herbage mass accumulation than the treatments subjected to infre- 
quent defoliation. This difference occurred because the development of the reproductive tillers was restricted in $\mathrm{F}+$, which provided the highest proportion of dry matter in the Ftreatments (Figure 4b). The visual inspection of the treatment coordinates allows observing two SDC phases. One with a steeper slope, similar to that of phase 2 presented in Figure $1(\mathrm{~F}+\mathrm{I}-\mathrm{vs} \mathrm{F}+\mathrm{I}+)$, had an increased tiller size and without important changes in tiller density. Another one with a slope of $-1 / 2(\mathrm{~F}+$ I- vs. F- I+), with intense and infrequent defoliation, led to a lower tiller density, although with higher herbage mass than the frequent and less intense defoliation. In this case, the value obtained (-1.79) was also less negative than the theoretical value, -2.50 . Like in May, the difference would have been reduced with the $\mathrm{C}_{\mathrm{r}}$ correction.

In December, with low values of density and herbage mass, none of the treatments could reach the SDC line (Figure 4c). The prairie grass reproductive period that occurs in this season limits tillering, especially in the treat- ments subjected to frequent and intense defoliation.

The SDC theory partially explains the variations between herbage mass and tiller density in dense swards of tall fescue and prairie grass in the North of Buenos Aires province. The previous evidence suggests that, in order to increase tiller density as a mechanism to optimize the forage accumulation, it would not be recommended to subject the sward to frequent and intense grazing in summer. This management could be beneficial only in early fall.

Tall fescue shows mechanisms of size/density compensation of tillers in dense canopies once the nutritional limitations are overcome. The knowledge of these mechanisms helps in making management decisions that optimize forage accumulation and quality (Table 4).

Prairie grass behaviour differs from that of tall fescue. The mechanism of size/density compensation is less frequent and shows less plasticity and a higher critical defoliation height in comparison to other species.

Table 4. Tiller density. Leaf Area Index (LAI) and $\mathrm{C}_{\mathrm{a}}$ value in prairie grass swards with different defoliation managements.

\begin{tabular}{|c|c|c|c|c|}
\hline \multirow[b]{3}{*}{ Variable } & \multicolumn{4}{|c|}{ Period } \\
\hline & \multicolumn{2}{|c|}{ May 2000} & \multicolumn{2}{|c|}{ September 2000} \\
\hline & $\mathrm{F}+\mathrm{I}+$ & F-I- & F-I+ & $\mathrm{F}+\mathrm{I}-$ \\
\hline Density (tillers $\mathrm{m}^{-2}$ ) & 940 & 2.558 & 1.491 & 1.985 \\
\hline $\mathrm{LAI}^{1}$ & 2.6 & 1.7 & 5.5 & 3.7 \\
\hline $\mathrm{C}_{\mathrm{a}}^{2}$ & \multicolumn{2}{|c|}{0.63} & \multicolumn{2}{|c|}{2.00} \\
\hline
\end{tabular}

${ }^{1}$ Estimated from Scheneiter and Rimieri (2001) and Scheneiter (2000); ${ }^{2} \mathrm{C}_{\mathrm{a}}=\left(\log _{10}\left(\operatorname{LAI}_{\mathrm{tx}}\right)^{3 / 2}-\log _{10}\left(\operatorname{LAI}_{\mathrm{ty}}\right)^{3 / 2}\right) /\left(\log _{10}\left(\right.\right.$ tillers $\left.\mathrm{m}^{-2}{ }_{\mathrm{ty}}\right)-\log _{10}\left(\right.$ tillers $\left.\left.\mathrm{m}^{-2} \mathrm{tx}\right)\right)$ 


\title{
Resumen
}

\begin{abstract}
J. Scheneiter y S. Assuero. 2010. La densidad de la población de macollos y la productividad de pasturas de festuca alta y cebadilla criolla. Cien. Inv. Agr. 37(2): 35-44. En este trabajo se estudió la relación entre la acumulación de forraje y la densidad de macollos, según la teoría de la compensación tamaño/densidad, en pasturas de festuca alta (Festuca arundinacea Schreb.) y cebadilla criolla (Bromus catharticus Vhal). En festuca alta, la información se obtuvo de un experimento que evaluó el efecto de dos niveles de fertilización nitrogenada, dos arreglos de siembra y dos frecuencias de pastoreo sobre disponibilidad de forraje y la densidad de macollos. En cebadilla criolla, por su parte, la información correspondió a un experimento en el cual se evaluó la acumulación de forraje y la densidad de macollos de pasturas manejadas con una combinación de dos frecuencias y dos severidades de defoliación. En festuca se observaron mecanismos de compensación tamaño/densidad de macollos una vez que las limitaciones nutricionales fueron superadas. La cebadilla criolla mostró menos plasticidad que festuca alta y el mecanismo de compensación tamaño/densidad fue menos evidente.
\end{abstract}

Palabras clave: Festuca arundinacea, Bromus catharticus, fitomasa, macollos, compensación tamaño/densidad.

\section{References}

Bertín, O.D. 1988. Los modelos de una pastura de festuca alta bajo diferentes regímenes de defoliación. INTA. Estación Experimental Agropecuaria Pergamino. Carpeta de Forrajeras y Producción Bovina. Resultados Comprobados 59. 3 pp.

Campo, S.E., M.A. Marino, F. Lattanzi, and M. G. Agnusdei. 1998. Crecimiento inverno primaveral de cebadilla criolla y raigrás anual. Páginas 125 126. In: Resúmenes $22^{\circ}$ Congreso Argentino de Producción Animal. Río Cuarto, Córdoba.

Chapman, D.F., and Lemaire, G. 1993. Morphogenetic and structural determinants of plant regrowth after defoliation. Proceedings of the XVII International Grasslands Congress. p. 95-104

Marino, M.A., and M.G. Agnusdei. 2004. Claves para lograr pasturas productivas de alta calidad nutritiva para el ganado: fertilización estratégica y manejo del pastoreo. In: Reunión Anual sobre Forrajeras: Producción de pasto de calidad. Pergamino, Estación Experimental Agropecuaria. 16 de Noviembre. 9 pp.

Martínez Calsina, L., S.G. Assuero, M.G. Agnusdei, and H.G. Pérez. 2008. Compensación tamaño/ densidad en macollos de Chloris gayana (Kunth) cultivar Finecut bajo diferentes regímenes de defoliación. In: Resúmenes $31^{\circ}$ Congreso Argentino de Producción Animal. Potreros de los Funes, San Luis, 15-17 de octubre. p. 383-384.
Matthew, C., G. Lemaire, N.R. Sackville Hamilton, and A. Hernández Garay. 1995. A modified self-thinning equation to describe size/density relationships for defoliated swards. Annals of Botany 76:579-587.

Matthew, C., A. Hernandez Garay, and J. Hodgson. 1996. Making sense of the link between tiller density and pasture production. Proceedings of the New Zealand Grassland Association 57:8387.

Matthew, C., S.G. Assuero, C.K. Black, and N.R. Sackville Hamilton. 2000. Tiller dynamics of grazed swards. Pages 127-151. In: G. Lemaire, J. Hodgson, A. de Moraes, C. Nabinger, and P.C. de F.Carvalho (eds.). Grassland Ecophisiology and Grazing Ecology. CABI Publishing, University Press, Cambridge, UK.

Parsons, A.J. 1988. The effects of season and management on the growth of grass swards. Pages129-177. In: M.B. Jones, A. Lazemby (eds.). The Grass Crop. The Physiological Basis of Production. Chapman and Hall Ltd. London, UK.

Rolhauser, A.G., S. Cepeda, P.H. Maseda, J.L. Rotundo, A.M. Srur, R.J. Fernandez, C.M. Ghersa, R.J.C. León, S.B. Perelman, W.B. Batista, and M.R. Aguiar. 2007. Efectos de la frecuencia de corte y la fertilización nitrogenada sobre la estructura de una población implantada de Festuca arundinacea Schreb. Ecología Austral 17:89-98

Sackville Hamilton, N.R., C. Matthew, and G. Lemaire. 1995. In defense of the- $3 / 2$ boundary rule: 
a re-evaluation of the self-thinning concepts and status. Annals of Botany 76:569-577.

Scheneiter, O., F. D'Andrea, C. Marcomini, and E. Pagano. 2001. Acumulación de forraje en pasturas base gramíneas con dos alturas de pastoreo. INTA, Estación Experimental Agropecuaria Pergamino. Revista de Tecnología Agropecuaria 6:44-48.

Scheneiter, O., C. Matthew, and P. Rimieri. 2008. The effect of defoliation management on tiller dynamics of prairie grass. Revista Argentina de Producción Animal 28:7-20.

Warton, D.I., I.J. Wright, D.S. Falster, and M. Westoby. 2006. Bivariate line-fitting methods for allometry. Biological Reviews 81:259-291.

Xia, J.X., J. Hodgson, and A.C.P. Chu. 1994. Effects of severity of grazing on tissue turnover in Matua prairie grass. New Zealand Journal of Agricultural Research 37:41-50. 